\title{
Process of construction of an educational booklet for health promotion of pregnant women ${ }^{1}$
}

\author{
Luciana Magnoni Reberte ${ }^{2}$ \\ Luiza Akiko Komura Hoga ${ }^{3}$ \\ Ana Luisa Zaniboni Gomes ${ }^{4}$
}

This study aimed to describe the production process of an educational booklet focusing on health promotion of pregnant women. The action research method was used in this process composed of the following steps: choice of the content based on the needs of pregnant women, creation of illustrations, content preparation based on scientific literature, validation of the material by experts and pregnant women. This work resulted in the final version of the booklet, which was entitled "Celebrating life: our commitment with the health promotion of pregnant women". Active participation of health professionals and pregnant women through dialogue and collective strategy permeated the process of development of the booklet. The opinions of pregnant women and experts who considered the booklet enriching and enlightening justify the use of it as an additional resource of educational activities carried out during the prenatal care.

Descriptors: Pregnancy; Health Promotion; Teaching Materials; Nursing.

\footnotetext{
${ }^{1}$ Paper extracted from Master's Dissertation "Celebrando a Vida: Construção de uma Cartilha para a Promoção da Saúde da Gestante", presented to Escola de Enfermagem, Universidade de São Paulo, SP, Brazil. Supported by Conselho Nacional de Desenvolvimento Científico e Tecnológico (CNPq), process \# 472875/2008-6.

2 Nurse-midwife, Doctoral Student in Nursing, Escola de Enfermagem, Universidade de São Paulo, SP, Brazil. Scholarship holder from Conselho Nacional de Desenvolvimento Científico e Tecnológico (CNPq). E-mail: lu.mare@ig.com.br.

${ }^{3}$ Nurse-midwife, Free Lecturer, Associate Professor, Escola de Enfermagem, Universidade de São Paulo, SP, Brazil. E-mail: kikatuca@usp.br.

${ }^{4}$ Journalist, M.Sc. in Communication. E-mail: analuisa@obore.com.
}

Corresponding Author:

Luciana Magnoni Reberte Gouveia

Rua Henrique Chaves, 305, 41B

CEP: 05372-050, São Paulo, SP, Brasil

E-mail: lu.mare@ig.com.br 


\section{O processo de construção de material educativo para a promoção da saúde da gestante}

Este estudo teve como objetivo descrever o processo de construção de uma cartilha educativa destinada à promoção da saúde da gestante. Utilizou-se a pesquisa-ação como método de pesquisa, e essa foi desenvolvida em cinco etapas: escolha do conteúdo, com base nas necessidades das gestantes; criação das ilustrações; preparação do conteúdo, baseado na literatura científica; validação do material por peritos e gestantes. O trabalho resultou na produção da versão final do material em formato de cartilha, que teve o título "Celebrando a Vida. Nosso compromisso com a promoção da saúde da gestante". A participação ativa dos profissionais e das gestantes, com o uso de estratégia dialógica e coletiva, permeou o processo de construção da cartilha. As opiniões das gestantes e dos peritos, que consideraram a cartilha enriquecedora e esclarecedora, justificam o uso da cartilha como recurso adicional das atividades educativas, realizadas durante o período pré-natal.

Descritores: Gravidez; Promoção da Saúde; Materiais de Ensino; Enfermagem.

\section{El proceso de construcción de material educativo para la promoción de la salud de la gestante}

Este estudio tuvo por objetivo describir el proceso de construcción de una cartilla educativa destinada a la promoción de la salud de la gestante. Se utilizó la investigaciónacción como método de investigación, que fue desarrollado en cinco etapas: elección del contenido, con base en las necesidades de las gestantes; creación de las ilustraciones; preparación del contenido basado en la literatura científica; y validación del material por expertos y gestantes. El trabajo resultó en la producción de la versión final del material en formato de cartilla, que tuvo el título de "Celebrando la vida: Nuestro Compromiso con la Promoción de la Salud de la Gestante". La participación activa de los profesionales y de las gestantes, usando una estrategia dialógica y colectiva, impregnó el proceso de construcción de la cartilla. Las opiniones de las gestantes y de los expertos, que consideraron la cartilla enriquecedora y esclarecedora, justifican el uso de la cartilla como un recurso adicional de las actividades educativas realizadas durante el período prenatal.

Descriptores: Embarazo; Promoción de la Salud; Materiales de Enseñanza; Enfermería.

\section{Introduction}

The use of educational printed materials in health care is a common practice in the Brazilian Unified Health System (SUS). Handbooks for health care, guidelines, information leaflets and booklets are able to promote expressive outcomes for the participants of educational activities (1). The contribution of these materials to health promotion depends on the principles and ways of communication involved in the process of elaboration.

Communication models based on dialogue and multi-directive principles allow the existence of dialogue among people involved in the process of construction of the booklet (2). The interaction and exchange of knowledge in view of people's life-style is an essential aspect of this process (3). The analysis of booklets available for pregnant women who receive prenatal care at a Unit of the SUS located in the city of Sao Paulo, southwestern of Brazil, permitted the observation of the absence of participative and communicative approach in their process of elaboration ${ }^{(4-5)}$.

The adoption of these approaches is considered essential for the existence of correspondence between the needs of pregnant women and the contents of a booklet.

Based on this premise, a prenatal educational activity with participation of pregnant women and their spouses in a group was carried out before the development of this research. The educational activity 
was developed in a participative way during the whole process and health educational needs were identified. The acquisition of these data was an essential step for the production of the educational material and contents according to the needs of the pregnant women and their partners. This group of eight women and four spouses was conducted by a nurse midwife and a nursing student, at the outpatient department of a university hospital located in the city of Sao Paulo.

The action research method was used in all group sessions ${ }^{(6-7)}$. All the participants were requested to express their own needs, in a participative and communicative manner. The participants of the group evaluated positively the strategy. They mentioned the benefits derived from the strategy and the feeling of freedom to express their own doubts and opinions. The action research method permitted the choice of the theme in the next group session, as well as the choice of the better educational strategy according to the participants' interests ${ }^{(8)}$.

The World Health Organization (WHO) $)^{(9)}$ and the Brazilian Health Ministry (MS) ${ }^{(10)}$ recommended the adoption of strategies aimed at the interests of pregnant women in prenatal care. Since 1984, when the Women's Integral Health Care Program (PAISM)(11) was implemented by the Brazilian Federal Government, the Ministry of Health stimulated the development of educational actions aimed at improving the health of pregnant women. Currently the "Humanization of the Prenatal Care Program" (PHPN) ${ }^{(12)}$, which is integrated to the "National Policy for Women's Integral Health Care" (13), highlighted the essential role of women's perspective in educative actions.

The correspondence between interests and needs of the readers of booklets is a fundamental element in the process of construction of this kind of educational resource. The quality of the booklet as well as adequacy of language and illustrations are relevant (14). A high quality educative material requires reliable information and the use of clear vocabulary in order to permit an easy understanding of its contents (15).

This work was written considering the importance of these aspects in the process of constructing educative materials and the lack of a booklet directed to pregnant women, which are constructed in a participative and communicative manner. The study aimed to describe the process developed in the elaboration of a booklet for pregnant women.

\section{Methodology}

\section{Theoretical framework}

Socio-constructive pedagogy, the theory developed by Paulo Freire, was used in the development of the booklet. This author influenced a new conception of empowerment, a key health promotion concept. The empowerment leads to social changes, and it is a result of the acquisition of knowledge related to discursive, cognitive and procedural capabilities (16). In education, the empowerment occurs in a context of dialogical learning. Educators and students are subjects of an educative process, and opportunities for knowledge are created with the participation of both subjects ${ }^{(3,17)}$.

Freire's educational philosophy promoted empowerment around the world. This educator defends the perspective that awareness is a continuous cycle, which is composed of dialogue and action. Interaction among people, when permeated by dialogue and critical reflection, enables the development of participatory and collective action. These actions, in turn, generate more reflections and further actions. Thus, a constant circle of actions and reactions are constituted (18).

\section{Research design}

The action research method was followed during the whole development process of the booklet. The main presupposition of this method is the construction of knowledge in collective and participatory ways, in order to find a solution for a problem that needs to be studied. The solution found can produce positive reflexes for people, community, and society ${ }^{(6)}$.

This process was composed of five phases (Figure 1), carried out in the period from October 2007 to October 2008.

Editorial and layout work
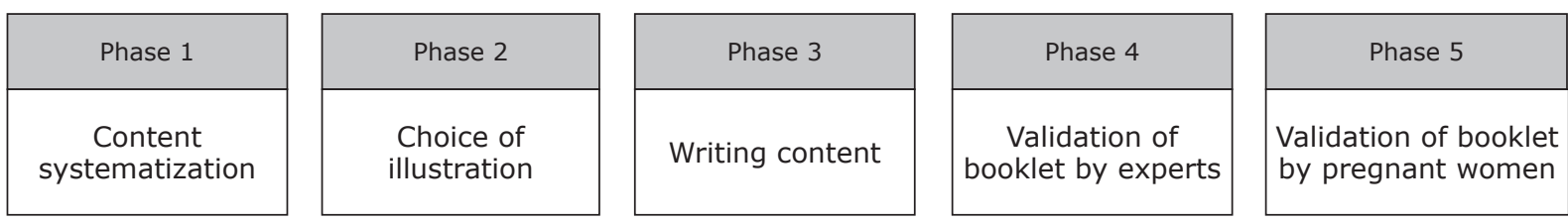

Editorial and layout work

Figure 1 - The booklet construction process 
The first phase was based on the needs of pregnant women and their spouses. These data were obtained when the researchers carried out nine health education meetings with a group of pregnant women and their spouses. The preliminary collection of data occurred at the outpatient department of a university hospital. The pregnant women and their spouses were invited by the nurse to participate in the group. In the first group meeting, the participants were requested to express their doubts and educational needs. They were also requested to express their preferences regarding the ways in which the meetings could be conducted. At the end of the meetings, the participants were requested to evaluate the approached contents and the educative methods utilized in the previous group meeting. The use of these resources permitted the identification of the participants' own requirements, and promoted an active contribution in the elaboration of contents and the choice of strategies to be utilized in the next educational meeting. All meetings were tape recorded and transcribed verbatim. These data were used to guide the elaboration of the topics of booklet and main contents.

The elaboration of the content was based on scientific literature in order to guarantee reliability. Some information related to public services available for pregnant women was included in the booklet, and the reliability was confirmed by phone or e-mail.

In the second phase, text books and images on electronic pages were accessed in order to find better illustrations. Didactic images were selected and used as the basis for the elaboration of the illustrations, a work performed by a professional specialized in this issue.

In the third phase, the preliminary content was developed with attention given to the information considered as essential. This content was submitted to the editorial and layout work. The development of this phase was based on the criteria previously established for the whole booklet construction process, i.e., easy reading and content clarity.

The first version of the booklet was submitted to the evaluation of experts who validated it. The criteria adopted for the inclusion of health care providers as experts were: work in a prenatal care setting; have previous experience in health promotion activities, and have experience regarding validation of educative and didactic materials. Professional councils, organizational managers, and health care service managers were requested to introduce the professionals to accomplish the booklet validation process.
In this fourth phase, a questionnaire was used for the validating process ${ }^{(19)}$. The questions were related to adequacy of information and language and illustration. For each topic of the booklet, professionals evaluated the adequacy of information, and if it was appropriately presented, considering the reader's perspective. Regarding language they evaluated the convenience and the ease of understanding, and if the most important concepts were approached in a clear and objective vocabulary. They also indicated possible conceptual errors. Regarding illustrations, they evaluated the appropriateness of visual composition, its attractiveness and organization as well as the quantity and adequacy of the illustrations. At the end of the validation, they were requested to provide a general opinion about the booklet. Their recommendations were integrally accepted and incorporated in the booklet. The booklet's new version was submitted to another edition, revision and layout process.

In the fifth phase, the pregnant women were invited to participate in the study when they were waiting for a prenatal care appointment at a Public Health Care Unit in the city of Sao Paulo. The criteria adopted for the inclusion of pregnant women were: receive prenatal care, and have some literacy skills, i.e., know how to write and read. They were requested to read the booklet and analyze it in terms of understanding the vocabulary, as well as the adequacy of illustrations. They were also requested to indicate the unknown or difficult terms, and to suggest other substitutive terms considered easier and understandable.

The validation process made by the experts and pregnant women was carried out until the lack of new recommendations for changes. This criterion was followed to determine the quantity of pregnant women included in this study.

The research project was approved by the Research Ethics Committee (protocol number 660/2007) and all participants signed an informed consent term, according to the Helsinki Declaration (20). In the informed consent for the pregnant women and professionals, the aims and procedures of their participation were presented.

\section{Results}

This study was composed of 17 collaborators, 8 experts and 9 pregnant women. The experts were two nurse midwives, two obstetricians, one nursing auxiliary (NA), one licensed practical nurse (LPN), one physical educator and one registered nurse specialized in health 
promotion. Six of them had the title of specialist, two had master degree and two had PhD degree. Seven were working in a health care unit, four were professors, and three were researchers.

The pregnant women were from 15 to 33 years of age. Their occupations were the following: students (3), cleaners (2), housewives (2), supermarket worker (1) and unemployed (1). Years of formal education varied from primary to the university levels. All of them were living near to the Public Health Care Unit. The gestational ages were from 16 to 35 weeks; five of the pregnant women were having their first pregnancy, three of them were having their second pregnancy, and one had six pregnancies.
The first version of the booklet had 48 pages. It was printed in red and blue colors and the title was "Celebrating Life: Our Commitment with the Health Promotion of Pregnant Women". This title was maintained until the final version of the booklet.

In the experts' validation process, suggestions related to information, language, and vocabulary were given. The main suggestions given for inclusion of information are shown in Figure 2. Moreover, they suggested the reformulation and exclusion of information, and reformulation of illustrations and vocabulary. The suggestions for inclusion were followed considering the editorial criteria and the scientific perspectives.

\begin{tabular}{|c|c|}
\hline Subject & Suggestions \\
\hline Pregnancy changes & $\begin{array}{l}\text { Relate headache with an emotional state } \\
\text { Associate vomiting in pregnancy with weight loss } \\
\text { Recommend oral hygiene and dental treatment } \\
\text { Recommend adequate eating habits to family members } \\
\text { Recommend water intake to prevent urinary tract infection }\end{array}$ \\
\hline $\begin{array}{l}\text { Development of } \\
\text { pregnancy and baby } \\
\text { growth }\end{array}$ & $\begin{array}{l}\text { Link tobacco, alcohol and other drugs to risks for the mother and baby } \\
\text { Indicate support services for chemically dependents } \\
\text { Recommend attention to hygiene and temperature of swimming pool for practice of physical activity } \\
\text { Indicate the frequency and duration of walking for pregnant women } \\
\text { Encourage dialogue between the pregnant woman and her husband }\end{array}$ \\
\hline Childbirth & $\begin{array}{l}\text { Indicate the possibilities of choice for labor support } \\
\text { Clarify rights related to humanization of labor } \\
\text { Explain contractions characteristics on the days before the onset of labor }\end{array}$ \\
\hline Postpartum & $\begin{array}{l}\text { Recommend physical activities for pregnant woman together with her baby } \\
\text { Recommend condoms for birth control }\end{array}$ \\
\hline Breastfeeding & $\begin{array}{l}\text { Recommend hydration to stimulate production of breast milk } \\
\text { Advise about the risks of tobacco, alcohol and other drugs } \\
\text { Include the characteristics of breast milk } \\
\text { Include explanation about HIV vertical transmission } \\
\text { Include the rights of mother students } \\
\text { Indicate services to guarantee work rights }\end{array}$ \\
\hline The Newborn & $\begin{array}{l}\text { Include the importance of family dialogue for child development } \\
\text { Recommend hygiene on the umbilical stump } \\
\text { Recommend hygienic diaper-changing } \\
\text { Explain the characteristics of crying } \\
\text { Warn about risks of smoking }\end{array}$ \\
\hline Body Care & Recommend practices of body care for family members \\
\hline
\end{tabular}

Figure 2 - Suggestions made by experts for inclusion of information in the text according to the subject of the booklet

All the experts performed a positive evaluation of the booklet. The language was considered easy to understand and this aspect was highlighted as vital to promote the interests of pregnant women.

The main suggestions of pregnant women are shown in Figure 3. All pregnant women performed a positive evaluation of the booklet. They considered that this kind of resource should be available for other pregnant women, considering its importance for doubt explanations and orientations, especially for pregnant women who have difficulties to access other kinds of information. 


\begin{tabular}{|l|l|}
\hline \multicolumn{1}{|c|}{ Words } & \multicolumn{1}{c|}{ Suggestions } \\
\hline Flexible Muscles & More flexible muscles and better prepared to move \\
\hline Your own milk can be used as a lubricant & Your own milk can be used for hydrating \\
\hline Water aerobics & $\begin{array}{l}\text { The exercises such as swimming and gymnastics (water aerobics) that can be done in the water } \\
\text { such as in a swimming pool }\end{array}$ \\
\hline
\end{tabular}

Figure 3 - Suggestions made by pregnant women to change the vocabulary and words are listed according to their substitution in the booklet

The pregnant women's own interpretations related to the booklet were the following:

I am an expectant mother and I love this booklet. It teaches a lot of things and clarifies my doubts about baby movement and its causes. Also, it explains about the couple e.g., if we are allowed to have sexual intercourse in this period (T.A); this booklet should be given to pregnant women by primary services and hospitals to explain doubts. I enjoyed and learned things that I did not know. Thank you (T.A); I thought this work was very important because it is good for those who have little understanding about this, those who cannot study, and those who don't have an orientation (G.S.F); I am a six-time pregnant woman and I know all about it, I thought it was a wonderful booklet and I did not have difficulty understanding the content, It will be great for other pregnant women (S.P.B).

Their suggestions were included and also submitted to the editorial team, layout and final art process.

\section{Discussion}

The adoption of the participative, communicative, and collective approach is recommended for the process of construction of the educational booklet. Its feasibility permits us to recommend the adoption of this approach for other initiatives.

In the process of construction of health education resources, the existence of a close interaction among the involved people is recommended (2). This interaction, associated with the commitment of the participation for the health promotion, is the main premise of the actionresearch methodology.

The content systematization procedure allows the review and up-to-date the content preserved after the group's prenatal educational activity. The orientations given were based on scientific background. However, the participant's preferences, as well as, the culture and the professional judgment should be considered in the health education process ${ }^{(21)}$.

The participation of experts in the evaluation of the booklet allows the adequacy of content to professional's work context. The attendance of the participant's expectations, which could have different knowledge and interest in relation to who elaborates educative materials is considered essential in the process of construction of the educational resource ${ }^{(1)}$.

The contribution of a professional specialized in communication was essential. This professional contributed to the conceptualization of the material, the editorial and layout work, since the beginning of the process. The participation of a professional specialized in communication is recommended in the process of the construction of such materials. In the framework of the SUS, there is a criticism directed to the lack of inclusion of these professionals. Usually, these professionals work only in a part of the process. Their participation in few steps of the process can result in fragmentation and prejudice the final quality of the educational materials (22). In this work, this fragility was overcome. The specificities of the knowledge of each professional were considered, and all of them have been involved in the whole booklet construction process.

The contribution of booklet readers, in this case, the pregnant women, permitted the construction of a booklet with easy vocabulary and illustrations. The evaluation of the booklet by the pregnant women demonstrated that its content was written according to their reality of life, considering their positive evaluation of the booklet.

In this way, the participative approach utilized during the phase of women's educational needs was fundamental. This approach permitted the active contribution of pregnant women in the indication of the booklet's contents, in order to correspond to their own demands. The search for collective solutions makes people work in their own issues and overcome their own problems $^{(23)}$.

It is necessary to make it clear that the booklet should be considered as a complementary educational resource available for pregnant women. Its contents can help them to adopt the decisions related to care according to their own preferences and values ${ }^{(24)}$. The consideration of pregnant women's life experiences 
and values during the health care process is considered essential for their empowerment.

Above all, with the construction of the booklet, it was intended to overcome the hegemony that has been established in health education. This experience means to recognize the limitations of established knowledge and admit another, which is not specialized in the wide identification of health needs and understanding of the contexts of life and resources used by the population. This prerogative considers that the right entails overcoming the prejudice included in the representation of clients, which implies respect, and tries to understand another voice in order to influence the new culture of the health sector ${ }^{(25)}$.

The effectiveness of communication is one of the main aspects of human rights (26-27). In this way, throughout the booklet elaboration process, the dialogue relationship between professionals and people assumes a main role for effective communication in care settings. In this situation, the professional hegemony would be overcome in the educational activities, and it requires a reflective attitude in the communication process ${ }^{(26)}$.

\section{Conclusion}

The main purpose of the creation of this booklet was to strengthen the potential of pregnant women and their family members and to promote health condition. The booklet is a support to professionals and pregnant women to overcome doubts and difficulties permeating the pregnancy and birth process.

The web version of the booklet is available to the public through the University web site. It represents an important step to improve the access to readers, but it is not enough to represent a source widely used by users of SUS through the availability of the print version in public health institutions.

It is highlighted that this booklet received a grant from the Incentive Award in Science and Technology for the SUS in 2009. It was recognized by the Brazilian Ministry of Health and it was released in different media. However, many efforts should be made to make the booklet available in a printed version for pregnant women attended at the SUS services. Further studies should be conducted to evaluate the effectiveness of the booklet as a source of information on prenatal care.

\section{References}

1. Echer IC. The development of handbooks of health care guidelines. Rev. Latino-Am. Enferm. 2005;13(5):754-7.
2. Carvalho MAP. Construção compartilhada do conhecimento: análise da produção de material educativo. In: Ministério da Saúde (BR). Secretaria de Gestão Estratégica e Participativa. Departamento de Apoio à Gestão Participativa. Caderno de educação popular em saúde. Brasília; 2007. p. 91-101.

3. Freire P. Pedagogia da autonomia: saberes necessários à prática educativa. 37a. ed. São Paulo: Paz e Terra; 2003

4. Montano RS. Hospital Universitário da Universidade de São Paulo (HU-USP). Ambulatório. Manual da gestante. São Paulo; [s.d].

5. Secretaria de Estado da Saúde (SP-BR). Coordenadoria de Planejamento de Saúde. Departamento de Atenção Básica. Agenda da gestante. São Paulo: IMESP; [20042005].

6. Thiollent M. Metodologia da pesquisa-ação. $14^{a}$ ed São Paulo: Cortez; 2005.

7. Brydon-Miller M, Greenwood D, Maguire P. Why Action Research? Action Research 2003;1(1):9-28. doi: 10.1177/14767503030011002.

8. Hoga LAK, Reberte LMR. Action-research as a strategy to develop pregnant women group: the participants perception. Rev Esc Enferm USP. 2007;41(4):559-66.

9. Di Mario S, Basevi V, Gori G, Spettoli D. What is the effectiveness of antenatal care? Copenhagen: World Health Organization; 2005. 25p. Supplement. [acesso 7 out 2010]. Disponível em: www.euro.who.int/ Document/E87997.pdf

10. Ministério da Saúde (BR). Secretaria de Políticas de Saúde. Parto, aborto e puerpério: assistência humanizada à mulher. Manual técnico. Brasília; 2001.

11. Formiga JFN Filho. Políticas de saúde reprodutiva no Brasil: uma análise do PAISM. In: Galvão L, Diaz J. Saúde sexual e reprodutiva no Brasil: dilemas e desafios. São Paulo: Hucitec; 1999. p. 104-62.

12. Ministério da Saúde (BR). Programa de Humanização do Pré-Natal e Nascimento. Informações para gestores e técnicos: manual técnico. Brasília; 2007.

13. Ministério da Saúde (BR). Política Nacional de Atenção Integral à Saúde da Mulher. Princípios e Diretrizes. Brasília; 2004. 82 p.

14. Wilkinson AS, Miller YD. Improving health behaviors during pregnancy: A new direction for the pregnancy handheald record. Aust N Z J Obstet Gynaecol. 2007;47:464-7.

15. Enkin M, Keirse MJNC, Neilson J, Crowther C, Duley L, Hodnett E, et al. Guia para atenção efetiva na gravidez e no parto. $3^{a}$ ed. Rio de Janeiro: Guanabara Koogan 2005. 
16. Carvalho SR. The multiple meanings of empowerment in the health promotion proposal. Cad Saúde Pública. 2004;20(4):1088-95.

17. Freire P. Pedagogia do oprimido. 41a ed. São Paulo: Paz e Terra; 2005.

18. Wallerstein N. What is the evidence on effectiveness of empowerment to improve health? WHO Regional Office for Europe's (Health Evidence Network Report); 2006. [acesso 1 set 2010]. Disponível em: http://www. euro.who.int/Document/E88086.pdf

19. Luz ZMP, Denise NP, Rabello A, Schall V. Evaluation of informative materials on leishmaniasis distributed in Brazil: criteria and basis for the production and improvement of health education materials. Cad Saúde Pública. 2003;19(2):561-69.

20. WMA (World Medical Association). Declaration of Helsink. Edimburg Scothland 52nd General AssemblyWMA. 13 october 2000. [acesso 5 fev 2010]. Disponível em: http://www.wma.net

21. Pearson A, Wiechula R, Court A, Lockwood C. The JBI Model of evidence-based healthcare. Int JEB Healthcare. 2005;3(8):207-15.

22. Montoro T. Communication frames on health: challenges and perspectives. Interface Comun Saude Educ. 2008;12(25):445-8.

23. El Andaloussi K. Pesquisa-ações: ciências, desenvolvimento, democracia. São Carlos: EduFSCar; 2004.

24. Araújo I. Materiais educativos e produção de sentidos na intervenção social. In: Monteiro S, Vargas E, organizadores. Educação, comunicação e tecnologia educacional: interfaces no campo da saúde. Rio de Janeiro: FIOCRUZ; 2006. p. 252.

25. Stotz EN, Araújo JWG. Health promotion and political culture: reconstructing the consensus. Saúde Soc. $2004 ; 13(2): 5-19$.

26. Diniz CSG. O que nós profissionais de saúde podemos fazer para promover os direitos humanos das mulheres na gravidez e no parto. São Paulo: Coletivo Feminista Sexualidade e Saúde; 2003.

27. Gruskin S, Cottingham J, Hilber AM, Kismodi E, Lincetto O, Roseman MJ. Using Human Rights to improve maternal and neonatal health: history, connections and a proposed practical approach. Bull WHO. 2008;86(8):589-93. 